\title{
Eukaryotic Translation Initiation Factor 3 Subunit E
}

National Cancer Institute

\section{Source}

National Cancer Institute. Eukaryotic Translation Initiation Factor 3 Subunit E. NCI

Thesaurus. Code C17917.

Eukaryotic translation initiation factor 3 subunit E (445 aa, $\sim 52 \mathrm{kDa}$ ) is encoded by the human EIF3E gene. This protein is involved in both translation initiation and nonsense mediated mRNA decay. 